\title{
Introduction
}

When we began this project, we suspected that there had been more women contributing to the development of our discipline than economists knew about. William Baumol's 'Digression: On Earlier Writings by Women', in an article on the centenary of the American Economic Association, reported that 'before World War I, as today, a (distressingly) few women were contributing to the literature' (Baumol, 1985, p. 11), noting that his research assistant had found seven articles (one in two parts) by four women. We knew that they missed at least one. Katharine Coman's article filled the first 19 pages of volume 1, number 1, of the American Economic Review. We knew of Barbara Libby's quantitative studies of the participation of women in the American economics profession (Libby, 1984, 1987, 1990). And we had some sympathy for Baumol's research assistant because we knew how easy it is to miss women who use initials rather than first names, especially if you search using the Index of Economic Journals. Economica, vol. 1, no. 2 (May 1921), for example, includes not only an article by Mabel C. Buer, but also an article by Miss E.T. Kelly and Miss M.L. Haskins (Kelly and Haskins, 1921, pp. 11631), while vol. 1, no. 3 has an article by Margaret S. Miller, but also an article by Miss W.A. Mackenzie (Mackenzie, 1921, pp. 211-30). The Index omits the honorific 'Miss'.

Since we began the research leading up to this volume, there has been a tremendous amount of new work on the subject. We soon learned that the proportion of women among contributors to the 'Old Palgrave', R.H. Inglis Palgrave's Dictionary of Political Economy, was slightly higher than that of The New Palgrave (Eatwell et al., 1987), published almost a century later (see Dimand, 1999). Barbara Libby's (1998) analysis continues. Peter Groenewegen and Susan King (1994) published an important working paper that listed 112 women (6.78 per cent of contributors) who published 222 articles (5.3 per cent of the total) in five core British and American economics journals from 1900 to 1939 . Robert Dimand extended this search to the 1890s, and found 44 articles by 30 women in the Quarterly Journal of Economics (founded 1886), the Economic Journal (1891) and the Journal of Political Economy (founded 1892). The other two journals used by Groenewegen and King, Economica and the American Economic Review, did not exist in the $1890 \mathrm{~s}$. The only essays co-authored with a man were two that Beatrice and Sidney Webb published (Dimand, 1999). Michèle Pujol (1996) and Kirsten Madden (1998) presented papers on the contributions of women 
economists to History of Economics Society conferences. The preparatory work for a Routledge anthology of economic writing by women before 1900, undertaken by Pujol before her death, is being completed by Janet Seiz. Groenewegen published the results of a symposium on women economists in Australia held at the University of Sydney in 1997 (1998, cf. Groenewegen, 1994). N.G. Butlin, V.W. Fitzgerald and R.H. Scott (1986) reported on the activity of women in The Australian Economist in the 1890s, and Judith Alexander (1995) survey their participation in Canada. We also began to develop a new appreciation for women whose contributions to economics appeared in books rather than in the journal literature, and whose analysis challenged our understanding of how the discipline of economics ought to be conceived. Charlotte Perkins Gilman's institutional analysis published in The Home: Its Work and Influence (1903) and Women and Economics (1898) is an example of such work (see M.A. Dimand, 1995).

We began to trace these leads, and discovered that looking for women economists is like pulling on a loose thread. Every woman we discovered led us to two or three more whose work they cited, or with whom they co-authored articles or books. They led us to others they mentored, or with whom they studied or worked. Women economists kept appearing in the oddest places. Looking back, it now seems almost inevitable that the project would grow beyond our expectations, as we rather belatedly began to follow the lead of other disciplines and take notice of the women who contributed to our history. Mary Jo Deegan's Women in Sociology (1991) and Mary Ellen Waithe, the editor of the four-volume A History of Women Philosophers, also began modestly: 'I decided to attempt to restore women's contributions to the history of philosophy, and initially believed that the subject would make an interesting article for, say, the Journal of the History of Philosophy' (Waithe, 1987, vol. I, p. x). And so we faced our first decision: how should we decide whom to include? Some of our decisions were necessarily arbitrary. We chose not to include the relatively large generation of women economists currently active in the profession. Most of our subjects are either dead or retired, although some of the more prolific continue to produce articles well into their nineties. We chose to focus on economists who were important, either because they made a substantive contribution to the field or, in a few cases, because they were historically important, such as being the first woman (of whom we were aware) in a particular country to contribute to the discipline. We tried to extend the coverage to non-anglophone traditions, but we were very dependent upon the willingness of collaborators to assist us. We were more successful in some languages, such as Japanese because of Aiko Ikeo's work and German thanks to Harald Hagemann and Claus-Dieter Krohn, than in others. Chinese and Latin American economists are virtually absent from this book. Indeed, we wish we knew more about such women as Mabel 
Ping-Hua Lee (born 1897), whose book Economic History of China (1921) was her Columbia University Ph.D. dissertation.

We also had to decide how to delimit the discipline of economics. We are editing this volume primarily for the use of economists, hoping that some will be sufficiently intrigued by the stories we have collected to do further work on these women and on their insights. Therefore, we wanted to define the discipline in such a way that present economists would recognize it. But we are mindful of the relatively recent domination of our discipline by pure theory, or what He Qinglian called 'techniques of dragon slaying' in her bestselling and controversial book entitled China's Pitfall (1996; see Liu and Link, 1998). We did not want to define economics so narrowly that we eliminated virtually all of the women and most of the men working in the past. The further back we go, the less clearly is economics distinguished from sociology and the related disciplines. So we decided to include individuals who were intentionally working in what would, at the time they wrote, have been considered economics. We included, for example, the consumer economists working in departments of home economics and government departments of agriculture early in this century. But we excluded people who were primarily social activists or journalists who, occasionally, wrote on topics related to economic reform. Many of the women attached to the Saint-Simonian movement in nineteenth-century France, such as Suzanne Voilquin, were excluded, while Julie-Victoire Daubié, the first woman baccalaureate in France (in 1862), was included. Her articles in the Journal des Économistes (1862, 1863 ) and her 1866 book on women and poverty, works which systematically examined economic issues, justified her inclusion.

The most difficult decision we faced, however, was to send the manuscript to the publisher. This project was beginning to take on the air of Scheherazade's Tales. Some contributors submitted a piece, and then sent rather desperate messages begging to revise because they found new and really interesting material. Others became so intrigued by their subjects that one- to twothousand-word articles turned into much longer pieces, only some of which were successfully shortened. Some kept turning up new names and new people who ought to be included. And others ran into difficulty finding material on women who ought to have been included, or were so meticulous that the articles never appeared. We do not present this volume as an exhaustive account of women's contributions to the discipline. We know that there are women who really ought to have been included and yet, for one reason or another, were not. We have also developed enough humility to know that there are many women in the history of our discipline of whom we remain ignorant. This volume is produced with the hope that some readers will be inspired to help us fill the gaps in our institutional memory. 


\section{What have we learned?}

\section{The nineteenth century}

Priscilla Wakefield's criticism of Adam Smith's Wealth of Nations is our earliest inclusion (Wakefield [1798], 1817). She faulted Smith for insufficient coverage of the economic activity of women, both in the sphere of household production (which he had excluded from economic analysis on the grounds that it was not governed by considerations of rational self-interest) and in the realm of wage work and market activity. Sophie de Grouchy, the marquise de Condorcet, had translated Smith's Theory of Moral Sentiments into French in 1798, and appended eight letters on the subject of sympathy which constitute a significant treatise on moral philosophy. She did discuss economic issues and, for example, was much more critical of inequality of wealth than was Smith, but this was not primarily a work in economics. Wakefield, by contrast, protested against the exclusion of women from Smith's Wealth of Nations raising at the time concerns that feminist scholars have more recently emphasized (Pujol, 1992; Rendall, 1987). 'Does it matter to the relevance of his doctrine', Michèle Pujol asked (1992, p. 22), 'that at least half of the human race is not allowed to be freely guided by self-interest?' In his unpublished Glasgow lectures, Smith had followed Montesquieu in discussing the social status of women in different historical stages of economic development (Chris Nyland, 1993), but they disappear from the Wealth of Nations.

The classical neglect of women's economic contributions continued. Neither David Ricardo's Principles of Political Economy and Taxation, nor T.R. Malthus's Principles of Political Economy mention women. Jean-Baptiste Say, by contrast, developed a patriarchal analysis of women's social roles alongside his market analysis (Forget, 1997). Robert Owen and John Bray, British Utopian socialists, presented an analysis 'infused with paternal imagery' (Nancy Folbre, 1993, p. 97), a criticism that could be levelled with equal justice against Barthelémy-Prosper Enfantin, the Saint-Simonian theorist who argued that women were inherently different from men and ought to retire from active participation in economic activity until the new world to be created by Saint-Simonian activities comes about.

But there were women economists writing during the classical period. Frances (Fanny) Wright, one of the women mentioned in Dorfman's monumental The Economic Mind in American Civilization was a popular lecturer and leading figure in Utopian communities at Nashoba, Tennessee (where she helped to resettle slaves whose freedom she had purchased) and, with Robert Owen, at New Harmony, Indiana. She was a social reformer with outspoken views on religion, marriage and education rather than an economist systematically contributing to economic analysis. The same can be said of Anna Wheeler, sometime collaborator with the British Utopian socialist William 
Thompson (Folbre, 1993, p. 98), and of Saint-Simonians such as Suzanne Voilquin (Moses, 1984).

More familiar to most economists are the popularizers, Jane Marcet and Harriet Martineau. Since Marcet (1816) and Martineau (1832-34) sold better than the monthly instalments of Dickens's novels, it is perhaps not necessary to mention that they also outsold classical theorists such as Ricardo (Polkinghorn, 1993, 1995). Marcet is often written of as making Ricardo accessible, a considerable feat since her book appeared the year before his (Dimand, 1995, pp. 12-13). While she knew Ricardo, who recommended her book to his daughter, her value theory was actually closer to Say's utility theory than to Ricardo's, and she was less concerned than Ricardo or Malthus about population growth and natural resource scarcity (Polkinghorn, 1993, pp. 52-5). Martineau's Illustrations of Political Economy (1832-34) also helped to popularize political economy, but she distanced herself from this early dogmatism in her autobiography (1877, vol. I, pp. 194-5). Martineau questioned those aspects of factory legislation that limited women's opportunities for employment (1855). Her Society in America ([1837], 1962) included a chapter on the status of women in America, contrasting their low wages and restricted property rights with the American ideology of equality (Frawley, 1992).

Barbara Leigh Smith Bodichon drafted the petition to Parliament that led to the Married Women's Property Act (1857) and the petition for women's suffrage that John Stuart Mill presented to Parliament in 1866 (Robson and Robson, 1994, pp. xxvi-xxviii). She also founded the Society for Promoting the Employment of Women and the English Woman's Journal, and wrote on Women and Work (1857) and on laws affecting women. In the 1860s, Bodichon and her Langham Place associates were introduced to John Stuart Mill by his stepdaughter, Helen Taylor. Mill's views on the social and economic roles of women were influenced by his wife, Harriet Taylor. Pujol (1992, 1995), however, argues that Taylor's views were more radical than those of Mill. Millicent Garrett Fawcett $(1892,1918)$ was also a visitor to Langham Place and, by the time of her Economic Journal articles, widow of Henry Fawcett (who had been MP for Brighton and Professor of Political Economy at Cambridge).

Women were active in the National Association for the Promotion of Social Science, from its founding meeting in 1857 until its dissolution in 1886 (Cobbe, 1861; Rogers, 1952; Martel, 1986). Indeed, women were seen as changing the very nature of economic discourse. In 1876, Sir Francis Galton attempted to have Economics removed from Section F of the British Association for the Advancement of Science, and the following year the Adam Smith Centennial Dinner of the Political Economy Club broke into an acrimonious discussion of the nature of economics. Following the dinner, the Pall Mall Gazette reported that: 
the natural philosophers have been frightened out of their wits by the ladies who flock to the Section of 'Economic Science and Statistics' and who insist on reading papers and starting discussions which are not only not scientific but which savour of the singular antipathy to science for its own sake common to all the feminine movements of the day. (Pall Mall Gazette, 22 August 1878, p. 1, quoted in Jevons Papers \& Correspondence, iv, pp. 272-3n5) ${ }^{1}$

In France and America, women were also making their presence known.

Mary Meynieu wrote a popularizing Eléments d'économie politique (Elements of Political Economy) (1839) and Paupérisme anglais (English Pauperism) (1841). She published in the Journal des économistes in 1859 and, the following year, produced a pamphlet on women's work. Clémence-Auguste Royer published a two-volume Théorie de l'impôt, ou la dîme sociale (Theory of Taxation) (1862). She was primarily an anthropologist and writer on scientific issues such as Darwin's Origin of Species, which she translated in 1862, but published on broad sociological topics in the Journal des économistes in the 1870s. Julie-Victoire Daubié won a prize from the Academy of Lyons in 1859 with an essay on 'La femme pauvre au XIXe siècle' (The impoverished woman of the nineteenth century), which she published as a series of articles in the Journal des économistes in 1862 and 1863, and then as a book in 1866. Her work was accepted as part of the conversation of political economy, while Flora Tristan's criticisms of classical economics in her London Journal (1840) were treated as the work of an outsider. Ekelund and Hébert (1999, p. 427) note a letter from Walras to Mlle Guillaumin, 'who took over her father's publishing business on his death [in 1864] and acted as de facto editor of the Journal des économistes'. Palgrave's Dictionary, in an article on Urbain Gilbert Guillaumin, noted that 'Guillaumin's two daughters, of whom the eldest, Félicité died in 1885 at the age of fifty-six, inherited both his administrative ability and his devotion to economic science'.

Caroline Healey Dall considered the economic role of women in a series of public lectures in Boston, published as 'Women's Right to Labor' (1860). She served on the executive committee of the American Social Science Association from its foundation in 1865 until 1905, initially as a director and then, from 1880, as vice-president. Virginia Penny published The Employments of Women: A Cyclopaedia of Woman's Work (1863). The second printing was entitled Five Hundred Occupations Adapted to Women; with the Average Rate of Pay in Each and the third, How Women Can Make Money, Married or Single. The book reported on wages, gender pay differentials (both as stated by employers and as understood by the author), necessary skills and education, time needed to learn the job, seasonality, paid or unpaid apprenticeship, and openness to women. Think and Act: A Series of Articles Pertaining to Men and Women, Work and Wages (Penny, 1869) considered married women's property rights, domestic labour, market work, human capital, poverty 
rates of women relative to men and economic consequences, especially for women, of the Civil War.

\section{Consumer economics and the household}

From the time of Adam Smith, the household was customarily seen as outside the sphere of rational calculation and self-interest. A line of research initiated at Iowa State College and the University of Chicago by Elizabeth Ellis Hoyt (1928, 1938), Hazel Kyrk (1923, 1933) and Margaret Gilpin Reid (1934), however, attempts to bring concepts of economic efficiency to considerations of the allocation of time and other resources within the household. The 'new home economics' of Nobel Laureate Gary Becker builds on this tradition.

Women were also intensely involved in the empirical studies upon which postwar theories of consumption were based. Dorothy Stahl Brady and Rose Director Friedman (1946) anticipated the relative income hypothesis, for which the later publications of James Duesenberry are usually cited (Dimand, 1995, pp. 13-14). The permanent-income hypothesis of Milton Friedman (1957) and the life-cycle theory of Franco Modigliani were explicitly based upon empirical studies conducted by Dorothy Brady, Rose Friedman and Margaret Reid, a debt that both Friedman and Modigliani acknowledge. For these contributions, Reid was the first woman named Distinguished Fellow by the American Economic Association.

\section{Twentieth-century continental economics}

Rosa Luxemburg's 1897 University of Zürich doctoral dissertation in political science was published in 1898 as The Industrial Development of Poland, a year before V.I. Lenin's Development of Capitalism in Russia (1899). The Accumulation of Capital ([1913], 1951) was her major work, and a significant contribution to growth theory and Marxian macroeconomics. Natalie Moszkowska won her doctorate at the University of Zürich in 1917, with a dissertation on workers' savings banks in the Polish coal and steel industries. She worked as a tutor and wrote for the trade union and socialist press. Moszkowska criticized Marx's theory, of the tendency of the profit rate to fall in Das Marxsche System (1929) and Zur Dynamik des Statkapitalismus (1943). She offered an underconsumptionist theory of crises in Zur Kritik Moderner Krisentheorien (1935), and published three articles in a mainstream economics journal, Schmoller's Jahrbuch (1959, 1963, 1965). In the first, she compared Marx to Keynes, unfavourably, on crisis theory.

The study of peasant economies was a feature of Russian economics from the early 1890s. Two women economists contributed significantly to this area of study. F.A. Scherbina was the most prominent writer in the field, and S. Platova was one of the authors of Methods of Quantitative Calculation of the Effectiveness of Land, a 1925 study edited by A.V. Chayanov (Jasny, 1972). 
Chayanov's Institute for Peasant Studies was destroyed, along with N.D. Kondratieff's Business Cycle Institute, after the arrest and disappearance of Chayanov and Kondratieff. Associated with Kondratieff's Business Cycle Institute was another woman, O.E. Pryakhina, who was credited by Nikolai Kondratieff for the careful and critical statistical work upon which his The Long Wave Cycle was based (Kondratieff, 1984, pp. 34-5). When serious scholarly activity resumed in the Soviet Union after Stalinism, Olga Bondareva became a game theorist of international stature, the author of 70 papers and a book, and a member of the editorial board of Games and Economic Behavior.

Frieda Wunderlich earned her doctorate at the University of Freiburg in 1919 and became a professor at the University of Berlin before emigrating to be a professor of economics at the New School for Social Research in New York from 1933 to 1954. She published an article in the Quarterly Journal of Economics in 1928 on German unemployment insurance, and another in 1938 on 'Germany's defense economy and the decay of capitalism', 14 articles between 1934 and 1953 in the New School's journal Social Research on women's work in Germany, unemployment insurance, health insurance and the Beveridge plan, as well as books on German Labor Courts (1946) and Farm Labor in Germany, 1810-1945 (1961). Marie Dessauer earned a doctorate at the University of Frankfurt in 1933, with a doctorate on major English deposit banks. She emigrated to study at LSE (1934-36) and became a research assistant to T.E. Gregory and Friedrich Hayek (1937-41). She contributed articles on banking and unemployment to the Review of Economic Studies, Economic History Review and Economica.

Ilse Schueller Mintz, who earned a doctorate at the University of Vienna in 1927 under Ludwig von Mises' supervision, earned a second doctorate at Columbia in 1951. She taught at Columbia from 1948 to 1969, and from 1951 to 1973 was Senior Research Associate at the National Bureau of Economic Research, which published four books she authored.

Huguette Biaujeaud received a doctorate from the University of Paris in 1933 with a thesis on Ricardian value theory. She did not pursue her academic work further. This may well have been due to limited opportunities for academic employment in France: the only woman to hold a professorship in any discipline in interwar France was Marie Curie (appointed after her first Nobel prize). The Revue d'économie politique reveals only two articles by women between 1921 and 1934, one of which was written by the Swedish economist Karin Kock. French women economists such as Marguerite Thibert were, however, involved in international economic agencies such as the International Labour Office.

Karin Kock's Stockholm dissertation was published in English as A Study of Interest Rates (1929). She published primarily in Swedish, but did publish internationally on monetary economics and trade policy. She collaborated on 
the construction of retrospective national income accounts for Sweden. Kock became Sweden's first female cabinet minister, was head of the Central Bureau of Statistics from 1950 to 1958 and of the Swedish delegation to the UN Economic Commission for Europe from 1947 to 1960.

Aiko Ikeo's work on Japanese political economy brings to us the insights of such economists as Sumiko Takahara, who criticized the assumption of methodological individualism while arguing for the inclusion of women's household labour in economic analysis in a 1979 book entitled Challenging Male Economics (Ikeo, 1999, p. 590).

\section{Surveying women economists}

This introduction has not come close to mentioning all of the people and all of the stories contained in this volume, let alone all women contributors to our discipline. One of the things of which we have become aware is the incredible diversity in the writing of women economists. They did pay far more attention, proportionately, than did men to 'women's issues'. From Priscilla Wakefield [1798] and Julie-Victoire Daubié (1862, 1863) to Michèle Pujol (1992) to Heidl Hartmann (1981), critics have argued that economic theories, whether neoclassical, classical or Marxist, exclude the important work of household production and reproductive work from their analysis. Women labour historians, such as Edith Abbott, Alice Clark, Elizabeth Dexter, Bessie Leigh Hutchins, Annie Meyer, Ivy Pinchbeck, Helen Sumner and Caroline Ware, offer analyses of the past work experience of half the population, both in the household and in the marketplace.

Women devoted more interest than did men to social policy and gender pay differentials (Helen Campbell), but they also wrote on topics as diverse as Marxian macroeconomics (Rosa Luxemburg, Natalie Moszkowska), income distribution (Mary Jean Bowman, Selma Goldsmith), the economics of education (Mary Jean Bowman. Sophie Willock Bryant), the economics of racial and gender discrimination (Phyllis Wallace), exchange rates (Elisabeth Caroline Van Dorp, Joan Robinson), international trade theory (Marion Crawford Samuelson), monetary economics (Anna Schwartz, Helen Makower, Eleanor Lansing Dulles, Sara McLean Hardy, Margaret G. Myers), the theory of the firm (Joan Robinson, Edith Penrose), capital theory (Joan Robinson, Krishna Bharadwaj, Ruth Cohen (of the Ruth Cohen curiosum)), public finance (Ursula Hicks. Mabel Newcomer, Selma Mushkin), development (Elizabeth Boody Schumpeter, Irma Adelman. Ester Boserup, Polly Hill, Cynthia Taft Morris, Barbara Ward, Vera Smith Lutz), institutional economics (Charlotte Perkins Gilman) and the history of economic thought (Marian Bowley, Marjorie Grice-Hutchinson and Jacqueline Hecht).

Consumer economics, both in the form of the 'new home economics' and in empirical work behind innovations in the theory of the consumption 
function, owe much to Margaret Reid, Dorothy Brady. Rose Friedman, Elizabeth Hoyt, Hazel Kyrk and Ruby Turner Morris.

Economic history has always attracted the attention of women: Mabel Ping-Hua Lee's Economic History of China (1921), Margaret Stephenson Miller's Economic Development of Russia (1925), Vera Anstey's Economic Development of India (1929) are worthy of note. Mabel Buer, Ivy Pinchbeck and Elizabeth Gilboy wrote on topics related to the Industrial Revolution. Miriam Beard's History of Business (1938), Alice Hanson Jones's magisterial study of wealth distribution in colonial America, Anne Bezanson's work in price history, and, especially, Elizabeth Boody Schumpeter's work on commercial statistics, are significant pieces of work.

The political range of women economists was equally vast, ranging from the revolutionary Marxism of Rosa Luxemburg and Raya Dunayevskaya to Vera Smith Lutz's case for the free banking alternative to a central bank in a doctoral dissertation supervised by Hayek (Smith, 1936), and the anti-statist views of Suzanne LaFollette (1926). He Qinglian's dismissal of Chinese academic economics as either 'toady writing' (the construction of economic justifications for political decisions) or 'techniques of dragon slaying' (pure economic theory with no political or social referents), in a scathing criticism of recent Chinese economic history, reminds us of the territory we have not covered in this volume. Her China's Pitfall was published to critical acclaim in Hong Kong (1996) and was eventually published (under the less provocative title A Pitfall of Modernization (1998)) in China (see Liu and Link, 1998).

\section{An invitation}

The stories we have collected are fascinating. Enjoy. And keep looking ...

\section{Note}

1. We would like to thank Sandra Peart for drawing this article to our attention.

\section{References}

Alexander, Judith A. (1995), 'Our ancestors in their successive generations', Canadian Journal of Economics, 28(1): 205-24.

Anstey, Vera (1929), The Economic Development of India, London: Longmans, Green.

Baumol, William J. (1985), 'On method in U.S. economics a century earlier', American Economic Review, 75(6): 1-12.

Beard, Miriam (1938), A History of Business, 2 vols. Reprinted Ann Arbor: University of Michigan Press, 1962.

Butlin, N.G., V.W. Fitzgerald and R.H. Scott (eds) (1986), The Australian Economist 18881898, 2 vols. Sydney: Australian National University Press.

Cobbe, Frances Power (1861), 'Social science congresses and women's part in them', Macmillan's Magazine.

Daubié, Julie-Victoire (1862), 'Quels moyens de subsistence out les femmes', Journal des économistes, 2nd series (34).

Daubié, Julie-Victoire (1863), 'Travail manuel des femmes', Journal des économistes, 2nd series (38 and 39). 
Deegan, Mary Jo (ed.) (1991), Women in Sociology: A Bio-Bibliographical Sourcebook, New York: Greenwood Press.

Dimand, Mary Ann (1995), 'The Economics of Charlotte Perkins Gilman', in Dimand, Dimand and Forget (1995): 124-49.

Dimand, M.A., R.W. Dimand and E.L. Forget (eds) (1995), Women of Value: Feminist Essays on the History of Women in Economics, Aldershot, UK, and Brookfield, VT: Edward Elgar.

Dimand, Robert W. (1995), 'The neglect of women's contributions to economics', in Dimand, Dimand and Forget (1995): 1-24.

Dimand, Robert W. (1999), 'Women Economists in the 1890s: journals, books and the Old Palgrave', Journal of the History of Economic Thought, 21(3).

Dorfman, Joseph (1946-59), The Economic Mind in American Civilization, 5 volumes, New York: Viking.

Eatwell, J., M. Milgate and Peter Newman (eds) (1987), The New Palgrave: A Dictionary of Economics, 4 vols. London: Stockton Press.

Ekelund, Robert B. Jr and Robert F. Hébert (1999), The Secret Origins of Modern Microeconomics: Dupuit and the Engineers, Chicago: University of Chicago Press.

Fawcett, Millicent Garrett (1892), 'Mr. Sidney Webb's article on wages for women', Economic Journal, 2(1): 173-6.

Fawcett, Millicent Garrett (1918), 'Equal pay for equal work', Economic Journal, 28(1): 1-6.

Folbre, Nancy (1991), 'The unproductive housewife: her evolution in nineteenth-century economic thought', Signs: Journal of Women in Culture and Society, 16(3): 463-84.

Folbre, Nancy (1993), 'Socialism, feminist and scientific', in Marianne Ferber and Julie Nelson (eds), Beyond Economic Man, Chicago: University of Chicago Press.

Forget, Evelyn L. (1997), 'The market for virtue: Jean-Baptiste Say on women in the economy and society', Feminist Economics, 3(1): 95-111.

Frawley, Maria H. (1992), 'Harriet Martineau in America: gender and the discourse of sociology', Victorian Newsletter, 81: 13-20.

Gilman, Charlotte Perkins (1898), Women and Economics: The Economic Factor Between Men and Women as a Factor in Social Evolution, Boston: Small, Maynard. Reprinted (with an introduction by Carl Degler) New York: Harper Torchbooks, 1996. Reprinted Amherst, NY: Prometheus Books, 1994.

Gilman, Charlotte Perkins ([1903] 1970), The Home: Its Work and Influence, New York: New York Source Book Press.

Groenewegen, Peter D. (ed.) (1994), Feminism and Political Economy in Victorian England, Aldershot, UK, and Brookfield, VT: Edward Elgar.

Groenewegen, Peter D. (1998), 'Women economists in Australia', Economic Papers, 17(1).

Groenewegen, Peter D. and Susan King (1994), 'Women as producers of economic articles: a statistical assessment of the nature and extent of female participation in five British and North American journals 1900-1939', University of Sydney Working Papers in Economics no. 201.

Hartmann, Heidi (1981), 'The unhappy marriage of Marxism and feminism: towards a more progressive union', in Lydia Sargent (ed.), Women and Revolution, Boston: South End Press: $1-41$.

Hoyt, Elizabeth Ellis (1928), Consumption of Wealth, New York: Macmillan.

Hoyt, Elizabeth Ellis (1938), Consumption in Our Society, New York: McGraw-Hill.

Ikeo, Aiko (1999), 'Japanese political economy', in Phillip A. O'Hara (ed.), Encyclopedia of Political Economy, London and New York: Routledge.

Jasny, Naum (1972), Soviet Economists of the Twenties: Names to be Remembered, Cambridge: Cambridge University Press.

Kelly, E.T. and M.L. Haskins (1921), 'Foundations of industrial welfare', Economica, 1(2): 116-31.

Kondratieff, Nikolai (1984), The Long Wave Cycle, translated by Guy Daniels with an introduction by Julian M. Snyder, St Moritz, Switzerland: International Moneyline.

Kyrk, Hazel (1923), A Theory of Consumption, Cambridge, MA: Houghton Mifflin, The Riverside Press.

Kyrk, Hazel (1933), Economic Problems of the Family, New York: Harper and Brothers. 
LaFollette, Suzanne (1926), Concerning Women, New York: Albert and Charles Boni.

Lee, Mabel Ping-Hua (1921), The Economic History of China, with Special Reference to Agriculture, New York: Columbia University Press.

Libby, Barbara (1984), 'Women in economics before 1940', Essays in Economic and Business History, vol. 3: 273-90.

Libby, Barbara (1987), 'Statistical analysis of women in the economics profession', Essays in Economic and Business History, vol. 5: 179-89.

Libby, Barbara (1990), 'Women in the economics profession 1900-1940: factors in declining visibility', Essays in Economic and Business History, vol. 8: 121-30.

Libby, Barbara (1998), 'As time goes by: a chronological study of women in the economics profession', Essays in Economic and Business History, vol. 16: 261-76.

Liu Binyan and Perry Link (1998), 'A great leap backward?' (review of He Qinglian's China's Pitfall), New York Review of Books, 45(15): 19-23.

Mackenzie, W.A. (1921), 'Changes in the standard of living in the United Kingdom, 18601914', Economica, 1(3): 211-30.

Madden, Janice F. (1972), 'The development of economic thought on the "women problem", Review of Radical Political Economics, 4(3): 21-39.

Madden, Kirsten (1998), 'Female economists in the history of economic thought: methodological issues and a case study in consumption theory', Millersville University, presented to History of Economics Society.

Marcet, Jane Haldimand (1816), Conversations on Political Economy, London: Longman.

Martel, Carol F. (1986), 'British women in the National Association for the Promotion of Social Science, 1857-1886', unpublished Ph.D. dissertation, Arizona State University.

Martineau, Harriet (1832-34), Illustrations of Political Economy, 9 volumes, London: Charles Fox.

Martineau, Harriet ([1837] 1962), Society in America, abridged and edited by Seymour Martin Lipset, Garden City, NY: Doubleday Anchor. Reprinted New Brunswick, NJ: Transaction Books, 1981.

Martineau, Harriet (1855), The Factory Controversy: A Warning Against 'Meddling Legislation', Manchester: Ireland and Company and the National Association of Factory Operators.

Martineau, Harriet (1877), Autobiography, 2 volumes, M.W. Chapman (ed.), London: Smith, Elder.

Miller, Margaret S. (1925), Economic Development of Russia, London: P.S. King \& Son.

Moses, Claire G. (1984), French Feminism in the 19th Century, Albany: State University of New York Press.

Nyland, Chris (1993), 'Adam Smith, stage theory, and the status of women', History of Political Economy, 25(4): 617-40.

Palgrave, R.H. Inglis (ed.) (1894-99), Dictionary of Political Economy, 3 vols. London: Macmillan.

Polkinghorn, Bette (1993), Jane Marcet: An Uncommon Woman, Aldermaston, Berkshire: Forestwood Publications.

Polkinghorn, Bette (1995), 'Jane Marcet and Harriet Martineau: motive, market experience and reception of their works popularizing classical political economy', in Dimand, Dimand and Forget (1995): 71-82.

Pujol, Michèle (1992), Feminism and Anti-Feminism in Early Economic Thought, Aldershot, UK, and Brookfield, VT: Edward Elgar (paperback edn, with preface by Janet A. Seiz, Cheltenham, UK, and Northampton, MA: Edward Elgar, 1998).

Pujol, Michèle (1995), 'The feminist economic thought of Harriet Taylor (1807-58)', in Dimand, Dimand and Forget (1995): 82-102.

Pujol, Michèle (1996), 'Nineteenth century economic writing by women', paper presented to History of Economics Society, Vancouver.

Qinglian, He (1996), Zhongguo de xianjing (China's Pitfall), Hong Kong: Mingjing chubanshe. Reid, Margaret Gilpin (1934), Economics of Household Production, New York: John Wiley.

Rendall, Jane (1987), 'Virtue and commerce: women in the making of Adam Smith's political economy', in Ellen Kennedy and Susan Mendus (eds), Women in Western Political Philosophy: Kant to Nietzche, Brighton: Wheatsheaf Books. 
Robson, Ann P. and John M. Robson (eds) (1994), Sexual Equality: Writings by John Stuart Mill, Harriet Taylor Mill and Helen Taylor, Toronto: University of Toronto Press.

Rogers, Brian (1952), 'The Social Science Association, 1857-1886', The Manchester School, 20(3).

Smith, Vera (1936), The Rationale of Central Banking: And the Free Banking Alternative, London: P.S. King \& Son. Reprinted with an introduction by Leland Yeager, Indianapolis: Liberty Fund, 1990. (Later Vera Smith Lutz.)

Wakefield, Priscilla ([1798] 1817), Reflections on the Present Condition of the Female Sex, with Suggestions for its Improvement, 2nd edn, London: Darton, Harvey, and Darton.

Waithe, Mary Ellen (ed.) (1987), A History of Women Philosophers, 4 vols. Dordrecht: Martinus Nijhoff. 